\title{
The Power of Economic Ideas: Australian Economists in the Thirties
}

\begin{abstract}
Alex Millmow*
Abstract: $\quad$ This paper examines the struggle economists in interwar Australia faced in coming to terms with new ideas on economic philosophy and whether they, in fact, registered upon Commonwealth economic policy. After being unusually great in 1931, with the Premiers' Plan, the significance of economists waned as political complacency, brought about by the recovery itself, took over. Economists reasserted their influence, however, by the mid-1930s. This triumphant view of economists, however, finds little corroboration in Boris Schedvin's study of the depression in Australia, which quickly succeeded in changing the perception of Australian interwar economists, and their contribution to policy, from triumph to ineptitude. This paper rehabilitates the work of Australian interwar economists, arguing that they not only had an enviable international reputation but also facilitated the acceptance of Keynes's General Theory among policymakers before their counterparts did in the Northern Hemisphere.
\end{abstract}

\section{Introduction}

In the history of economic ideas there was a time, a brief interlude, when Australian economists came to the attention of their international counterparts. Australia in the interwar years sometimes resembled a laboratory for economic experiment. Australian economists were already influential in tariff-setting, economic development and wages policy. The Brigden report on the Australian tariff drew praise from the likes of Keynes and Taussig. However it was the Premiers' Plan of 1931, with its promise of constructive deflation as a means of economic readjustment, that provoked the most comment. The Australian Plan, as it was sometimes called, was hailed as an appropriate and uniquely improvised contribution to anti-depression policy. Keynes praised it, and the four economists principally behind it, for having 'saved the economic structure of Australia' (Keynes 1973b, p. 95). The economists concerned were D.B. Copland, Dean of the Faculty of Commerce at Melbourne University; his colleague, L.F. Giblin; E.O.G. Shann from the University of Adelaide; and his predecessor, L.G. Melville, who became the Commonwealth Bank's first economic adviser. Before 1939 it was widely accepted that Australian economists were not only instrumental but also quite correct in putting forward the Premiers' Plan to rescue Australia from total economic collapse (Corden 1968, p. 58; Dow 1937; Goodwin 1974, pp. 231-2; Hall 1938). It was only in the heyday of postwar 'hydraulic Keynesianism' that intellectual recrimination and revisionism began about the value of the Premiers' Plan. Colin Clark, one of the most prominent economists in Australia during the later 1930s, was critical of the Premiers' Plan. He accused his senior colleagues, with the exception of his mentor, J.B. Brigden, of sheepishly following public opinion in opting for balanced budgets, regardless of the state of the economy (1958, pp. 222-3).

In 1951 a somewhat penitent Douglas Copland, the chief architect of the Plan, looking back over the 1930 s, admitted that 'the mistake was made of not 
recognising clearly enough that government activities needed to expand tremendously to offset the fall in private spending' (1951, pp. 21-3). Copland also perceived errors in the conduct of economic policy, first in opposing monetary expansion, and second, and perhaps more forgivably, in seeing the depression purely in monetary terms $(1951$, p. 22$)$. He remained adamant, however, that if it had been too drastic an adjustment in costs '... it was a mistake in degree rather than principle' (Copland 1951, p. 23). In his last retrospective upon the Premiers' Plan, L.F. Giblin suggested that 'heavy unemployment was the inevitable price of national solvency' (a view candidly shared by Melville in personal communication with the author). Giblin went on to defend the plan, claiming 'that it was not far from the very best that was possible with a public inexperienced as it was at that time in violent economic vicissitudes and their remedies' (1951, p. 81). There the issue stood until the publication of Boris Schedvin's book Australia and the Great Depression (1970) put to an end to the heroic image of economists assiduously propagated by Copland. Schedvin critically questioned not just the role of economists' advice but also the actual effectiveness of the anti-depression economic policy that they helped formulate. Thereafter the Premiers' Plan became regarded in history textbooks as a terrible mistake, a case of misguided economic policy. The reputation of the men who devised it also became tarnished. The purpose of this paper is to repudiate both that conclusion and the book that contributed to that sentiment becoming established. Not only did Australia in the 1930s prove to be the 'utopia of practical economists' (Goodwin 1974, p. 236), but it also embraced the philosophy of Keynesianism with relative ease.

\section{The Economists and the Premiers' Plan: The Interwar View}

Copland claimed that Australia was one of the economies 'first in and first out' of depression. ${ }^{1}$ While the first half of that statement is indisputably correct, the second half is much more contentious. There is little debate, however, about the factors that caused the depression to hit Australia in the late 1920s. During that decade, Australian governments had undertaken a frenzy of developmental infrastructure works financed by loans from London. High opinion in London, from Montagu Norman to Keynes, looked askance on the scale of borrowing. Local economists, too, echoed these concerns about the indulgent rate of public spending, even if some of it would ultimately facilitate the rise of new manufacturing industries. When primary produce prices began to slip, making it increasingly difficult for state governments to service and repay their loans, the London capital market compounded their embarrassment by closing itself to any further Australian borrowing. The deterioration in the terms of trade, coupled with the cessation of long-term borrowing, spelt an immediate loss in national income of some ten per cent in one year alone (Copland 1934). Trying to increase export revenue as a way out of the crisis was ruled out because the global economy was, by this time, in the maw of depression. There were three ways in which Australia could react: default and some form of moratorium upon paying its foreign debt, financial reconstruction administered from London, or economic rehabilitation. To the credit of Australian policymakers only the last option was considered feasible.

In his account of the episode, Copland argued that Australia followed two distinct phases of policy response to the depression. The first was an experimental stage in which authorities, lacking both cohesion and direction, tackled the crisis from a short-term view. In the more lasting 'battle of the plans' phase, and 
thereafter, the federal government reluctantly called in the economists (Copland 1934). The four economists previously mentioned, were well-versed in giving practical advice to governments (Groenewegen and McFarlane 1990). The ideologically conservative pair, Shann and Melville, were both engaged in advising the two most powerful banks in the land, the Bank of New South Wales and the Commonwealth Bank respectively, the latter being Australia's nascent central bank. The Melbourne University men, Copland and Giblin, were economic stabilisationists not totally swayed by the virtues of deflation as Melville and, to a lesser extent, Shann were. The quartet decided early on to minimise their philosophical and policy differences in order to come up quickly with a scheme to restore budgetary equilibrium for Australian governments within three years.

In brief, the Premiers' Plan entailed three measures: a cut in government expenditure, a cut in interest rates, and the use of temporary deficit finance via Treasury Bills. In his copious writings on the plan, Copland always saw it in a much broader light, incorporating the earlier measures, taken elsewhere, to both cut real wages and devalue the Australian pound (Copland 1934, 1937). He saw the plan as achieving three things. First, it took the process of financial rehabilitation out of the political arena. Second, it put to death the inflationary schemes of price stabilisation being put about by monetary heretics within the Scullin Labor Government. And, third, the plan put Australia upon the road to a controlled deflation by adjusting her internal prices and costs in line with the fall in overseas prices. However the devaluation, together with the monetisation of the deficits, gave some stimulus to the economy. Melville insisted that these measures, together with the earlier increase in tariff levels ordered by the Scullin Government, gave local manufacturing an intentional boost (Melville 1971). In other words, the economists had, at the back of their minds, some notion of increasing Australia's import replacement capacity as a means of escaping the external constraint.

For Copland, the Premiers' Plan marked the mobilisation of economic expertise in the higher realm of policy making, even if office-holders did not at first realise it. He told Irving Fisher that 'Our economists and monetary advisers knew pretty well what they wanted, but I am quite sure that neither the Treasury authorities nor the Commonwealth Bank Board quite appreciated the nature and importance of the experiment they were conducting, ${ }^{2}$ In other words, it would be too much to claim that the authorities were wittingly practising a well-balanced expansionary policy, especially when it involved unorthodox measures. Copland never doubted the true authorship of the plan. Billed by Neville Cain as 'the public relations man of university economics', Copland saw the plan as a means of increasing the usefulness of economic advice, if not also advancing his own career (Cain 1980, p. 3). The Harvard economist, Frank Taussig, saluted him: 'Your own part gives one hope that after all, we economists are not so entirely useless as some of the critics allege's. Moreover Copland always took an extremely positive and expansive view of what the package actually entailed as well as the role of economists in carrying it through. Indeed Melville probably had Copland in mind when he reflected that some proponents of the Plan 'got a little hysterical about how good it was'. ${ }^{4}$. To Melville's eye, the plan was all about regaining budgetary balance, preventing capital flight and mastering the external debt problem, without driving the economy into the ground: 'I think perhaps we were a little Machiavellian about this. We thought that the proper way to get results was to talk deflation and inflate like hell, as a matter of tactics, particularly with the Commonwealth Bank Board. ${ }^{5}$ 
Copland, the political economist, par excellence, realised that dire circumstances brought economic advice to the fore. As he told the New Zealand Finance minister, Downie-Stewart: 'The early severity of the crisis forced drastic methods upon us and we were perhaps fortunate in not being in a position to make a deliberate choice. No doubt we would have failed to have taken the drastic action that we did $^{6}$. After the dust had settled Copland confided to Taussig that the Australian economists' ingenuity in masterminding the country's economic rehabilitation was only one side of the story. As he put it, 'it has been uncommonly successful, but it has been greatly helped by a run of good seasons. Whether we shall continue...depends more upon the courage we show and the psychology of the people than upon actual economic efforts themselves. If it succeeds it will at least establish the principle that 'intelligent economic control' is capable of handling a difficult situation with great advantage to all concerned'.

Copland gathered fame from the leading role he played in formulating the Premiers' Plan. In 1936, for instance, he was invited to Harvard University's Tercentenary celebrations, where he was rewarded with an honorary doctorate for, as he put it, 'recognition of the work the Australian economists have done for Australia over the past six years ${ }^{8}$. While impressed on an earlier trip to America by how their economists honeycombed the federal administration, Copland was critical of the Roosevelt administration's approach to solving the depression by increasing wages rather than using monetary policy. His Harvard address, entitled 'The State and the Entrepreneur', was apparently not well received by some. Copland bemoaned to a Melbourne colleague: 'Most of the economists (in the US) fail to see the necessity for social control and they spend their time beating the air about the interference of the Government with the economic law'.

An earlier honour for Copland was an express invitation from Keynes to give the 1933 Marshall lectures at Cambridge University. ${ }^{10}$ Copland took that opportunity to declare that the deliberate policies put in place by the Commonwealth Government were in part responsible for Australia's economic recovery (Cain 1980, p. 3). The overriding theme in the lectures, which were later published (Copland 1934), was that in facing a difficult price-cost problem Australia's economic institutions - the Arbitration Court, Loans Council, Commonwealth Bank and Tariff Board - allowed the economy to respond flexibly to the crisis. A unique middle road was taken, encompassing both cost cutting and a modest monetary expansion (Copland 1934, p. 69). In his lectures, Copland retold the story of how Australian economists had, from May 1930 onwards, played a prominent part in framing remedial policies. This was some achievement in a country said to despise scientific economics (Hancock 1930, p. 86). Economists wore that opprobrium, having made themselves distinctly unpopular in the $1920 \mathrm{~s}$ by warning against over-exuberant public spending.

The fact was, however, that Australian economists had begun to make inroads into government via the medium of committee work. In 1928, for instance, economists advised the Bruce-Page Government on the economic rationale for the Australian tariff, a practice Jacob Viner, while critical of the committee's findings, felt was worthy of imitation by other nations. Economists also had input into the Development and Migration Commission and other Committees of Inquiry (Cain 1973, pp. 79-80). The growing sense of professionalisation within economics was helped, too, by the placement of economists within the Commonwealth's public service from 1933 onwards (Petridis, 1981, p. 406). There was also the Commonwealth Grants Commission, established in 1933 to inquire into matters of 
economic equity between the states, largely at the behest of Giblin and Frederic Eggleston, a polymath who became its first Chairman. Australia's centralised wage-setting process, too, afforded a clear advantage in that it allowed an enviable degree of money wage flexibility in time of economic duress (Reddaway 1938, p. 335). The interaction between the Australian Loans Council and the Commonwealth Bank was also a 'guarantee' that a moderate policy outcome would be forthcoming (Copland 1937, p. 422).

Australian economists were influential not only because the general public had lost faith in its politicians, but also because they deliberately set out, unlike their British counterparts serving on the Economic Advisory Board, to be a small cohesive group with a fair degree of authority (Maclaurin 1936). Second, and just as important, the public statements made by economists struck a chord with the people $^{11}$. Non-partisan 'experts' might deliver Australia from the crisis better than any meddling politicians could (Nicholls 1992). As Grenfell Price, an Adelaide historian, put it: 'if ignorant politicians meddle in the delicate science of finance millions will undergo appalling sufferings' (cited in Nicholls 1992, p. 211). That they did, cemented the standing and prestige of interwar Australian economics. Richard Downing, then an economics student, captured the excitement of being taught by Copland and Giblin. They arrived 'to give their lectures straight from down-town meetings, and keeping us up-to-date with their day-to-day negotiations with governments and businessmen about depression, recovery...We were bred to the world of affairs, public policy and applied economics which they brought to the Melbourne school' (Downing 1971, pp. 466-7).

Not all, of course, welcomed the intrusion of economists upon the national scene. F.L. McDougall, the economic adviser at Australia House in London, agreed with David Rivett, Head of the Commonwealth Council for Scientific and Industrial Research, that the economists had 'lost their heads' with their new-found sense of importance. Sounding more like an aggrieved banker than the Government's chief scientist, Rivett explained how economists had come to prominence: 'My interpretation of the position is that the homo economicus Australiensis was a neglected species up to 1929. Then when depression broke upon us the harried politician hurried to him for aid and since that date your Giblins, Coplands, Shanns and Melvilles have been taken very seriously indeed. This sudden promotion of men whose experience in public affairs is limited seems to me to have had an unsettling effect upon their mental equilibrium' (cited in O'Dea 1997, p. 67). Someone else who also felt the economists had risen above their station was the indefatigable former NSW Premier, Jack Lang. In his recollection of the depression Lang devoted a chapter to Copland, incorrectly labelling him the 'torchbearer' for Niemeyerism (1962).

That aside, the overriding contemporary impression in the 1930s was that a small core of economists had pulled Australia back from the brink (Goodwin 1974; Maclaurin 1936). At the time Australian economists were universally hailed for the role they played in the crisis. At the Ottawa Imperial Trade conference in 1932, for instance, Shann reported: 'On all sides we are greeted by the remark that Australia has made the best stab of all at keeping her economy liquid and active" ${ }^{12}$. D.H. Robertson had Sweden and Australia in mind when he wrote: 'There are said to be, in the far north and far south, lands where economists all give the same advice, where the Government listens to it, where the public understands why the Government has listened...' (1940, p. 122). An Australian economist at Oxford, Robert Hall, believed the Premiers' Plan to set a marvellous example of what 
cohesive economic advice could achieve (Hall 1938, p. 120). Ralph Hawtrey felt that the Australians had anticipated the United States by seeking recourse from a brains trust (1934, p. 1). Even Keynes told one of his prize students, W.B. Reddaway, to spend some time in far-off Australia because there they listened to their economists (Tribe 1997, p. 77). Nigel Davenport, who penned the weekly Toreador column in the New Statesman and Nation, felt that the Australian government was unique in heeding the advice of its economists. ${ }^{13}$

Rupert Maclaurin, a young American scholar on a fellowship from Harvard University, writing on Australia's economic recovery for his dissertation, agreed with Copland's premise that, while needing some ration of luck, a small, open, pastoral-based economy could take measures to escape the slump (1936). He might have been helped to his findings by the fact that he was chaperoned and introduced to key players in the drama by Copland. More intriguing, however, was Maclaurin's view, seized upon later by Boris Schedvin, that Australian economists had, in fact, played only a spasmodic part in formulating recovery policy: '...the economists were used only in a haphazard fashion. That is to say, they were called on only on special tasks and with a particular problem to report on. And where they tried to broaden the bases of their inquiries in order to make their work more effective, governments not infrequently were resentful. Economists never had an opportunity to make a report on an entire economic program' (1936, p. 257). In other words, economists were never allowed full latitude in the policy advice they could convey to the Commonwealth. Despite this admission, the contemporary perception was that economists had indeed played a significant part in composing an economic plan that helped rehabilitate the Australian economy. Remarkably, Maclaurin's book remained the only in-depth study of the depression and its aftermath in Australia until the arrival of Schedvin's account.

\section{A Contrary View of Things}

The publication of Schedvin's book re-opened the debate over both the genesis and the economic soundness of the Premiers' Plan in dealing with Australia's debt and deflation problem. The central thesis of Schedvin's book was that '...deliberate policy measures were comparatively unimportant in influencing the nature of the contraction or the speed of recovery'. This view related to his other major finding, that 'Because imports fell more heavily than did national expenditure, the depression encouraged the shift of resources to the manufacturing sector; and it was on the basis of import replacement of manufactures that recovery was forged' $(1970$, p. 372). This did not totally square with how economists in the 1930s had perceived the factors driving the recovery process. They attributed it not just to public investment and the rise of manufacturing but also to the rise in business confidence stemming from the budgetary measures taken, together with the salve of rising wool prices.

Schedvin's book was not just a detailed narrative of the origins and impact of the depression, but also, and more importantly for our purposes, a study in the making of economic policy at the time. Its origins sprang from a doctoral dissertation from the University of Sydney entitled 'Economic Policy in Depression and Recovery in Australia 1927-1935'. While ostensibly a work in economic history, its focus upon the making of economic policy necessitated some inquiry into the ideas of economists. However, Schedvin undertook only a cursory examination of that aspect of the problem, possibly because he advanced the thesis that economic policy was, for the most part, market-driven. Economists, therefore, 
hardly mattered in the making of policy. The Board of the Commonwealth Bank and the other trading banks, together with a pliant Australian Loans Council, had prevailed over economic policy.

The recovery process, just like the responses to Australia's economic crisis, was essentially endogenously driven. Schedvin believed, therefore, that there had been much mythology about how the Plan was composed and ultimately put into place. It was not a case of deliberate economic policy urged on by 'experts' or economists, but rather responses that mirrored what would have been market outcomes. To that extent, the Premiers' Plan and the moves made upon wage levels and the exchange rate deserved little of the effusive praise that Copland and his contemporaries had showered upon it.

To Schedvin, 'The Premiers' Plan was merely the embodiment of a series of expedients designed to maintain external solvency. The plan was not conceived as a means to promote recovery, nor did it do so in any tangible way. The view that the Premiers' Plan was the foundation of Australia's recovery, that it represented a judicious and deliberate mixture of deflation and inflation is a figment of Sir Douglas Copland's imagination' $\left(1970\right.$, p. 7) ${ }^{14}$ Since the policies set out in the Premiers' Plan were essentially reactive and market-driven, Schedvin argued, economists were ciphers in the policy-making process; their primary function was to embroider the fabric of the Plan into a 'shroud of technical competence and expertise' (1970, p. 374). In short, where Copland sought to magnify the influence of economists upon policy, Schedvin sought to minimise it.

The germ of this minimalist view of economists and economic policy during the Great Depression came from Schedvin's doctoral supervisor, S.J. Butlin from the University of Sydney ${ }^{15}$. In his history of the Australia and New Zealand Bank, Butlin suggested that the measures that emerged from the 'battle of the plans' - for example, exchange depreciation and wage cuts - were actually 'the traditional responses of the free market'. He claimed that the so-called 'planning' of 1930-32 'was directed not to novel policies but to traditional ones dictated by inherited ways of thought; it represents rather the inevitable political process by which conflicting interests were finally brought to compromise, not a resolution of significant differences in policy' (1961, p. 390). In short, the Premiers' Plan was really a cosmetic exercise to disguise the primal political forces at play. Butlin dismissed the Premiers' Plan as merely invoking the simple national income welfare economics in Edwin Cannan's text Wealth but 'watered down' to the level of common discourse (Butlin 1948, p. 40). His austere view of the contribution of economists to public policy was, in turn, probably sparked by his long, close friendship with the historian, John La Nauze. In May 1937, La Nauze had written an article entitled 'Economic Theory and Practice', in which he argued that the actual influence of economists upon the shaping of public policy was vastly exaggerated, and sought to deflate the high-blown reputation of economists in rendering public service to their country in times of need. La Nauze concluded: 'In Sweden apparently economists enjoy the confidence and esteem of the public; in Australia, for a short time, some sections, at any rate, of the intelligent public were ready to believe that those who studied economic affairs might have some useful advice to offer upon there... On the whole it is unfair to say that economists are not regarded with relish by the public or even the intelligent majority of the public in most countries of the world today. They are sometimes listened to in Royal Commissions or similar bodies of inquiry; but with very few exceptions their advice or opinion finds no expression in government policy ${ }^{16}$. 
This went very much against the folklore about Australian economists at the time. La Nauze's provocative manuscript was never published nor is there evidence he ever sought to do so. As editor of the Economic Record, Copland might well have rejected the thrust of La Nauze's contribution, since he firmly believed that economists could improve public policy.

Given this antecedence, Schedvin probably went further than his mentor by castigating Australian economists for failing miserably to work towards the building of a positive policy in the later depression years, when this task was the preoccupation of overseas economists. When they should have been questioning traditional modes of thought, they clung to the myth of the efficacy of the Premiers' Plan and implicitly condoned thereafter the inept policies of the Lyons Government. There was nothing remotely comparable in Australia to the vigour of the New Deal or the Cambridge intellectual revolution' (1970, p. 225). Nor did Schedvin find any evidence of an intellectual hunger for experimentation within academe: 'There is nothing in Australia which even approximates the widespread intellectual reconsideration of traditional doctrines which occurred overseas' (1970, p. 374). This, Schedvin alleged, was because the major economists were not prepared to abandon the Premiers' Plan. This was certainly true up to 1932, when the economists pinned their hopes upon a further devaluation to create room for more domestic expansion via public works. When, however, this advice was rejected - due to the dominance of Sir Robert Gibson over the Commonwealth Bank Board - Giblin and Copland urged public stimulus even if it jeopardised both Australia's external account and her foreign exchange reserves. Closely following Butlin's line of thinking about the weight of inherited thought, Schedvin maintained that even if economists had had heterodox notions in their head, they were, in any case, quite powerless. Australia's economic parameters were governed by strong external and internal pressures.

Apart from Melville's protests, both in his verbal recollections of the period and in his review of Schedvin's book (Melville 1971), the aspersion upon the value of Australian economists during the 1930s has largely stood intact. The Australian economists who reviewed Schedvin's book took issue with his primary findings above the nature of the recovery process but did little to repudiate his claims about the alleged lacklustre performance of their profession in this decade (Boehm 1973; Forsyth 1972; Hancock 1971). Only Arndt (1971) assessed the advice of his adopted Australian forebears in any sympathetic light.

It was generally believed, therefore, that Australian economists had indeed performed poorly in the depression. In a reappraisal of the events of 1931, Sinclair argued that 'Australian governments had some freedom of action and failed to choose the fiscal action appropriate to the highest attainable level of employment' (1974, p. 58). He concluded that the timing of Premiers' Plan proved abysmal, in that the moment of external crisis had passed when the policy of sharp reductions in government expenditure began to take hold. Put simply, public policy exacerbated the slump. This view was shared by David Clark and Keith Hancock, both arguing that Australian economists' advice was rather inept in the circumstances (Clark 1976; Hancock 1971). The Premiers' Plan did not merely mimic the market but proved - in hindsight - needlessly deflationary (Hancock 1971, p. 77). Furthermore, the presumed reluctance to question deflationary policy in 1931 proved tragic, because the policy that stemmed from it was quite inappropriate. In terms of their assumptions and advice, Hancock judged that the economists had 'performed badly' (1971, p. 78). The steadfast 
reluctance to experiment, to authorise even modest public sector stimulus, even when pressure on Australia's foreign exchange eased, became starker by 1932 . By that time Australia suffered an unemployment rate (28\%) second only to Germany. The concerns of external balance and business confidence that preoccupied all the economists at the time were completely overlooked by David Clark in his traditional Keynesian retrospective of the episode (1976).

\section{A Reassessment}

Schedvin's observation about the lack of heterodox economic opinion among Australian economists during the early 1930 s can be refuted by briefly reexamining their activities down to 1935, the year in which Schedvin's original study ended. He completely overlooks, for instance, Copland and Giblin's support for Keynes's proposal to seek price level stabilisation, in the face of deflationary pressure, by resorting to cheap money and devaluation (Cain 1987a; Clark 1976; Endres 1987, p. 34). Neither does Schedvin discuss Keynes's extensive review of the Premiers' Plan encapsulated in his 'Report of the Australian Experts' (Keynes 1973b, pp. 94-102). While it is true that Keynes felt there should be a little more domestic stimulation rather than relying upon another devaluation, his Australian contemporaries, in contrast, wanted a devaluation first to give some buffer for the external account before engaging in public spending. As Melville wryly recalls, Keynes's refusal to sanction another devaluation of the Australian pound buttressed the central bank's opposition to that expedient ${ }^{17}$. Consequently the increased public spending that the Wallace committee had at the back of their minds was dispelled. Undaunted, Copland and Giblin pressed the authorities to increase spending on public works. Giblin, inclined even in 1931 towards some limited public spending upon rural infrastructure, found more practical inspiration in Keynes's (1933) pamphlet, The Means to Prosperity, with its message that an increase in expenditure would expand income rather than prices. He began to canvass that option among his colleagues. By 1935 Giblin had moved further, and expressed frustration at tampering directly with relative costs: 'A mere cutting of cost involving the vicious cycle of reduced income and reduced employment, is now generally recognised as no solution to the problem but rather calculated to prolong and intensify depression' (cited in Downing 1960, p. 45). In a confessional letter to the Sydney University economist, Ronald Walker, Giblin described how far his colleagues had come philosophically since 1930: 'Dyason was the one firm and consistent inflationist. Copland went that way in waves, with strong back eddies.... Melville of course was a strong deflationist. Melville gradually and reluctantly has moved a very long way, but with always a hankering backward, which finds voice from time to time. Shann, more fitfully, has moved even further the same way; and with his regret ${ }^{18}$. Copland candidly told the Premier of New South Wales, Bertram Stevens, whom he advised on economic policy, that his 1936 Harvard Oration - about how unfettered enterprise did not produce an economic and social order to satisfy the common man - was evidence of himself 'moving still further to the left'. ${ }^{19}$

In 1933 the General Manager of the Bank of New South Wales, Alfred Davidson, an active promoter of economics, had his research staff distribute a circular declaring that 'deflation in Australia has reached a point at which it may be dangerous to continue' (cited in Black 1995, p. 104). These actions, in tandem with the financial and political power of Davidson and Stevens, had some success in fortifying the Lyons Government against the Commonwealth Bank's desire to issue public loans solely to 
retire short-term debt. Had the Commonwealth Bank had its way, the ensuing tighter monetary conditions would have jeopardised the embryonic recovery.

Schedvin's reassessment of the worth of official economic policy during the depression is, moreover, at face value a little tendentious, for, as Forsyth noted, it is difficult to distinguish at times between the effect of policy and that of market forces, with each interacting on the other $(1972$, p. 376). As an example, take the exchange rate devaluation of January 1931, which, as Eichengreen argued, probably did more to aid the economic readjustment process than any other expedient (1988). Most would agree with Schedvin that it was indeed market forces that propelled cutting the link with sterling. That, however, is only half the story. The Commonwealth Bank, as guardian of the exchange rate, was quite prepared to use capital controls to uphold parity. It was Davidson who made the break, but with economists firmly by his side. Melville recalls that Shann, Copland and himself all of them quite unencumbered in their counsel - spent a weekend at Davidson's weekend retreat thrashing out the consequences of breaking the link with sterling ${ }^{20}$. Davidson, already instrumental in setting up the bank's economic intelligence and research section, with his old friend Shann at its head, wanted to anticipate the market and be 'in a position to influence events ${ }^{21}$. That wish surely never became more apparent than in January 1931. How Schedvin, who was the very first to have access to the Bank of New South Wales' archives, could overlook or disregard the role of economists in helping Davidson reach this crucial decision is quite mystifying. Schedvin was also the first scholar to exploit the Commonwealth Bank archival papers covering this period. Noel Butlin suggested that Schedvin had perhaps relied too much upon that archive, since his view on the proceedings of 1931 resembled that of Sir Robert Gibson, namely, that economic policy barely mattered in all the drama (Butlin 1970, p. 55). Gibson's successor as Chairman of the Commonwealth Bank Board, Claude Reading, was tarred with the same brush, attributing the recovery entirely to a revival in business confidence. 'What can policies accomplish?' he asked sceptically in one newspaper article. ${ }^{22}$

Schedvin also argues that economic policy was too deflationary and too cautious and that perhaps more (though he rarely says what) could have been done to alleviate the slump. In the psychological and economic setting in which Australia was placed, there could be little recourse to public sector stimulation of the economy in the 1930s. The commitment to balance budgets, albeit over a three-year term, was invoked by the economists and policy-making authorities in a bid to restore business confidence. As Shann, Copland and, further afield, Keynes emphasised, there were "powerful psychological forces working in favour of deflation at the time...' (Copland 1951, p. 21). Keynes had conceded that the success of fiscal policy depended upon how favourably it was seen by financial markets and the community. There could be, he said, 'enormous psychological advantages in the appearance of economy' (quoted in Middleton 1982, p. 56). In this respect, Keynes praised the restoration of Australian finances as readily as he had condemned their earlier profligacy (Markwell 1985, p. 19). Moreover, the guilt of the prodigal past hung in the air. Melville recalled that mere mention of a recurrence of 1920s-style public works sent 'a shiver through people's spines ${ }^{23}$. Copland felt that 'Australian governments had...shot their bolts before 1930 and so were in no position for bold initiatives' (cited in Endres 1987, p. 21). In short, Australian governments could not turn to public borrowing to engage in what Keynes called 'nature's remedy' to prevent a slump (Bland and Mills 1931, p. 162). Continuing deficit budgets, whether accidental or deliberate, were equated with 
default. Australia's foreign exchange reserves - the London balances - together with the repayment of overseas debt, precluded policy adventurism.

Despite its severity, the business and financial community drew, therefore, enormous psychological relief from the Premiers' Plan in the belief that it would rehabilitate Australia's finances. Moreover, leaving it to market forces to engineer the same relative adjustments would not have triggered the same response but would, more likely, have drawn social resistance. In addition, higher tariff protection gave the Federal Government some latitude in deploying some public works without putting pressure upon the exchange rate (Arndt 1971). Sinclair argues that the higher protection, partly at the behest of Australian economists, was in defiance of 'the rules of the game' permitted by the Gold Standard. This action, together with the then heresy of devaluation, was at odds with Sir Otto Niemeyer's advice that Australia should deflate its internal level of income to maintain parity with sterling (Sinclair 1974, p. 57). Copland likened a country on the Gold Standard to 'a ship tied to an anchor in a rough sea' ${ }^{24}$ The only option, then, was to cut free and ride the rough sea.

Melville, who helped devise the Premiers' Plan, rejected the Schedvin thesis and upheld the role of economists and the advice they gave to the Commonwealth Government. Their advice, he pointed out, not only prevented a breakdown of the monetary system but also played an important part in the recovery process (Cornish 1993, p. 17): 'The fact is that measures taken on wages, on the exchange rate, on budgets were the result of deliberate policy and were decisive in preventing the flight of capital and external default. ${ }^{25}$ In short, the Australian authorities had choices facing them in 1931 and, importantly, exercised them. Wage levels, for instance, were cut by the Arbitration Court on the grounds of national interest even though the Court was quite sympathetic to the interests of the worker. It was Copland, too, who gave expert evidence before the Court on the necessity for a real wage cut.

In his review of Schedvin's book, Melville expressed further bemusement at the view that the rise of the manufacturing sector was almost accidental. An ensemble of measures, including tariff protection, devaluation, a reduction in money wages and easy money, most of which were sanctioned by the authorities, had a deliberately beneficial impact upon manufacturing (Melville 1971, p. 145). Melville, like Copland and Giblin, wanted to see more domestic manufacturing capacity in place and advised accordingly.

Hancock noted that Schedvin's study devoted relatively little attention to the intellectual activities of economists after 1935. This corresponds, of course, with the end date of Schedvin's doctoral study. It did not prevent Schedvin, however, from asserting that little intellectual progression had been exhibited by Australian economists before 1939. However, even in the year Schedvin's study concludes, an expansionist, proto-Keynesian 'Sydney Plan' was prepared for the NSW Premier by five economists: Ronald Walker, Richard Mills, Hermann Black, William Wentworth and Douglas Copland. The kernel of it had been circulating for some period beforehand with the intellectual activities of Copland and Giblin. Schedvin's cut-off date means there is no detail, either, on the proceedings or the findings of the Royal Commission into Australia's financial system of 1936/1937. At that forum, university economists were by far the most influential group giving evidence, and put forward an impressive case for having the federal government determine monetary policy instead of the central bank (Sutherlin 1980). After finding that the Commonwealth Bank had erred, both in opposing devaluation and in failing to expand credit quickly enough during the depression, the Commission 
laid down policy guidelines with a Keynesian orientation. ${ }^{26}$ Melville, regarded by Groenewegen and McFarlane (1990, p. 143) as the most circumspect Keynesian of the four economists who concocted the Premier's Plan, is insistent that most Australian economists had accepted the conceptual framework of the General Theory by 1939 (Cornish 1993, p. 19). At the monetary policy level, Gilbert (1973) discerns possible signs of 'Keynesian' economic management in Australia as early as 1938 when she insulated herself from the effects of the Roosevelt recession by taking pre-emptive monetary policy action.

\section{Conclusion}

The Schedvin-Copland debate about how effective economists and economic policy actually were in combating the depression has a critical bearing upon the reputation of Australian interwar economists. If one adopts the Schedvin view that economists were, despite their public profile, only minor players in formulating Australian economic policy during the early 1930s, it lends support to the view that the ideas of economists had little impact, except when their ideas were in tune with prevailing political currents. It is true that the influence of Australian economists certainly reached a high point in 1931 and then faded somewhat over the next few years as recovery took hold. It is also true that Copland and his colleagues extracted capital from the Premiers' Plan, especially where it would promote the rising discipline of economics. Even in the lean years of the mid-thirties, Australian economists were a more imaginative and innovative force, in their conceptualising, advice and activities than Schedvin gave them credit for. They had to battle, too, against the stubborn and sometimes ultra-orthodox policies of the Commonwealth Bank Board, together with a government in the thrall of financial interests. Schedvin's related judgement, that Australian economists never strayed far from the framework of the Premiers' Plan, is a gross misrepresentation of both their vision and their intellectual hunger. Keynes believed that with the New Deal the United States was the economic laboratory for the world to test new economic doctrines. If one could overlook the special circumstances of the controversial 1931 wage cut, perhaps Australia would have better deserved that title. The esteemed Australian historian, W.K. Hancock (1930), had noted the tendency of social and economic developments in Britain to shadow the course already mapped out in his own country. Keynes was made personally aware of this after making demands for his favourite statistician, Colin Clark, to return to Cambridge from a visiting lectureship at the University of Melbourne. Clark wrote back: 'I am reaching the conclusion I want to stay in Australia. People have minds which are not closed to new truths, as the minds of so many Englishmen are: and with all the mistakes Australia has made in the past, I still think she may show the world, in economics...in the next twenty years' (Keynes 1973b, p. 808). Clark followed this up with another apologetic letter informing Keynes that the opportunity of 'putting economics into practice' by advising the Queensland Premier was a job offer that even Keynes would think twice about (ibid., p. 801).

* School of Management, Charles Sturt University, P.O. Box 588, Wagga Wagga, NSW 2678, Australia. Email: amillmow@csu.edu.au. An earlier version of this paper was given at the Fourteenth HETSA Conference at the University of Tasmania. I am indebted to those participants who commented on the paper and to 
the anonymous referees for feedback on this version. I would also like to extend a note of thanks to John King and Selwyn Cornish for comments on this paper.

\section{Notes}

1 Copland Transcript 1968, NLA, p. 10.

2 D.B. Copland to I. Fisher, 23/11/1934, University of Melbourne Archives, Faculty of Economics and Commerce Papers (hereafter UMA FECC), Box 23.

3 F. Taussig to D.B. Copland, 19/10/1931, UMA FECC, Box 17.

4 Melville Transcript 1971, NLA, p. 48.

5 Melville Transcript 1971, NLA, p. 34.

6 D.B. Copland to G. Downie-Stewart, 20/1/1933, UMA FECC, Box 19.

7 D.B. Copland to F. Taussig, 28/2/1933, UMA FECC, Box 19.

8 D.B. Copland to E.M. Morris, 15/6/1936, UMA FECC, Box 46.

9 D.B. Copland to G.L. Wood, 3/11/1936, UMA FECC Box 43.

10 J.M. Keynes to D.B. Copland, 19/5/1932, Keynes Papers, King's College.

11 D.B. Copland to B. Ruml, 15/12/1936, UMA FECC, Box 50.

12 E.O.G. Shann to A.C. Davidson, 27/7/1932, A-53-409, Bank of New South Wales Archive.

13 New Statesman and Nation, 12/12/1932, p. 866.

14 Schedvin is of the opinion that Australian authorities lacked the know how to mount a reflationary policy (1970, p. 373). According to the political scientist Ross McKibbin, a full-bodied economic reflation for Australia, or any other country for that matter in the thirties would have required 'extensive state supervision of the economy', which itself implied drastic political action (1990, p. 227). Germany under Hitler proved one exception. There was, in any case, an absence of 'a mature reflationary economics'. The alternatives open to Australia were not deflation or reflation but, in fact, drift or deflation (McKibbin, 1990, pp. 217; 224-5).

15 I owe this point to my doctoral dissertation supervisor, Selwyn Cornish, from the Australian National University.

16 'Economic Theory and Economic Practice' manuscript in John La Nauze papers, NLA, Mss 5248.

17 Melville Transcript 1971, NLA, pp. 22-3.

18 L.F. Giblin to E.R. Walker, 19/4/1934, NLA, Mss 366/5/81.

19 D.B. Copland to Premier Stevens, 27/7/1936, UMA FECC, Box 47.

20 Melville Transcript 1971, NLA, p.23.

21 'Intelligence department' handwritten notes by A.C. Davidson, General Manager

files GM302//289, Bank of New South Wales Archive.

22 'Progress of World Recovery during 1933', Sydney Morning Herald, 12/2/1934.

23 Melville Transcript 1971, NLA, p. 10.

24 D.B. Copland to J.J. Pelczyniki, 19/9/1934, UMA FECC, Box 25.

25 Melville Transcript 1971, NLA, p. 145.

26 Report of the Royal Commission into Banking and Monetary Systems, 1937, pp. 209-10.

\section{References}

\section{Primary Sources}

\section{University of Melbourne Archives}

Economics and Commerce: Correspondence, Lecture Notes, Articles, Journals. Reports relating to Professor D.B. Copland (1925-38). 


\section{Bank of New South Wales Archive (now Westpac)}

Papers of the General Manager: A.C. Davidson.

Files G.M. 302/289.

\section{National Library of Australia}

L.F. Giblin Papers Mss. 366.

L.G. Melville Transcript of interview (1971).

D.B. Copland Transcript of interview (1968).

\section{Modern Archives Centre, Kings College, Cambridge University}

Keynes papers.

\section{Newspapers}

'Progress of world recovery during 1933', Sydney Morning Herald, 12/2/1934.

'Toreador Column', New Statesman and Nation, 12/12/1932, p. 861.

\section{Secondary Sources}

Arndt, H.W. (1971) 'Review of B. Schedvin's “Australia and the Great Depression"”, Australian Quarterly 43(2), June, pp. 121-5.

Black, D. (1995) In His Own Words: John Curtin's Speeches and Writings, Sydney: Paradigm Books.

Boehm, E.A. (1973) 'Australia's economic depression of the 1930s', Economic Record 49(4), December, pp. 606-23.

Butlin, N.G. (1970) 'The depression', The Bulletin, 5 December. p. 55.

Butlin, S.J. (1948) 'Of course I know no economics...', Australian Quarterly 22(3), September, pp. 37-51.

Butlin, S.J. (1961) Australia and New Zealand Bank: The Bank of Australasia and the Union Bank of Australia Limited 1828-1951, London: Longmans.

Bland, F.A. and Mills, R.C. (1931) 'Financial reconstruction: an examination of the Plan adopted at the Premiers' Conference, 1931', Economic Record 7(13), pp. 161-76.

Cain, N. (1980) 'Monetary thought in the twenties and its depression legacy: an Australian illustration', Australian Economic History Review 20(1), March, pp. 1-27.

Cain, N. (1984) 'Economics between the wars: a tall poppy as seedling', Australian Cultural History 3, pp. 74-86.

Cain, N. (1987) 'Australian economic advice in 1930: liberal and radical alternatives', Canberra: Australian National University Working Papers in Economic History, No. 78, April.

Clark, C. (1958) Australian Hopes and Fears, London: Macmillan.

Clark, D.L. (1976) 'The Keynesian revolution and the Battle of the Plans', Economics 11(3), July, pp. 22-30.

Copland, D.B. (1934) Australia in the World Crisis, 1929-1933 (The Alfred Marshall Lectures delivered in the University of Cambridge, October and November 1933), Cambridge: Cambridge University Press. 
Copland, D.B. (1937) 'Australian policy in depression', in A.D. Gayer (ed.), Lessons of Monetary Experience, Farrar \& Rinehart, New York.

Copland, D.B. (1951) Inflation and Expansion: Essays on the Australian Economy, Melbourne: Cheshire.

Corden, W.M. (1968) Australian Economic Policy Discussion, Melbourne: Melbourne University Press.

Cornish, S. (1993) 'Sir Leslie Melville: an interview', Australian National University Working Papers in Economic History, No.173.

Dow, D. (1938) Australia Advances, New York: Funk \& Wagnall.

Downing, R. (1960) 'Giblin as Richie Professor', in D.B. Copland (ed.), Giblin: The Scholar and the Man, Melbourne: Cheshire, pp. 39-48.

Downing, R (1971) 'Sir Douglas Copland: a personal memory', Economic Record 47, December, pp. 465-9.

Eichengreen, B. (1988) 'The Australian recovery of the 1930s in international comparative perspective', in R.G. Gregory and N.G. Butlin (eds), Recovery from the Depression, Sydney: Cambridge University Press, pp. 33-60.

Endres, A.M. (1987) 'Structural economic thought in New Zealand: the inter-war contribution of A.G.B. Fisher', New Zealand Economic Papers 22(1), pp. 35-48.

Forsyth, P.J. (1972) 'Review of C.B. Schedvin's "Australia and the Great Depression", Economic History Review 25(2), pp. 375-6.

Giblin, L.F. (1951) The Growth of a Central Bank, Melbourne: Melbourne University Press.

Gilbert, R.S. (1973) The Australian Loans Council in Federal Fiscal Adjustments 1890-1965, Canberra: Australian National University Press.

Goodwin, C. (1974) The Image of Australia, Duke University Press.

Groenewegen, P and McFarlane, B. (1990) A History of Australian Economic Thought, London and New York: Routledge.

Hall, R.L. (1938) 'Review of "Economic Planning in Australia 1929-36", by W.R. Maclaurin', Economic Journal 48(189), March, pp. 119-21.

Hancock, W.K. (1930) Australia, London: Ernest Benn.

Hancock, K. (1971) 'Forty years on', Australian Economic History Review 12(1), March, pp. 71-9.

Keynes, J.M. (1973a) The Collected Writings of John Maynard Keynes, Volume XII, London: Macmillan and Cambridge University Press for the Royal Economic Society.

Keynes, J.M. (1973b) The Collected Writings of John Mayard Keynes, Volume XXI, London: Macmillan and Cambridge University Press for the Royal Economic Society.

Lang, J.T. (1962) The Great Bust: The Depression of the Thirties, Sydney: Angus and Robertson.

Maclaurin, W.R. (1936) Economic Planning in Australia 1929-1936, London: P.S. King.

Markwell, D.J. (1985) 'Keynes and Australia', Sydney: Reserve Bank of Australia Research Department Seminar Paper, September.

McKibbin, R. (1990) The Ideologies of Class: Social Relations in Britain 18801950, Oxford: Clarendon Press. 
Melville, L.G. (1971) 'Review of C.B. Schedvin's "Australia and the Great Depression"', Australian Journal of Politics and History 17(1), April, pp. 144-5.

Middleton, R. (1982) 'The Treasury in the 1930s: political and administrative constraints to acceptance of the "new" economics', Oxford Economic Papers 34(1), March, pp. 48-76.

Nicholls, P. (1992) 'Australian Protestantism and the politics of the Great Depression, 1929-31', Journal of Religious History 17(2), December, pp. 210-21.

O’Dea, C.M. (1997) Ian Clunies Ross, Melbourne: Hyland House.

Petridis, R (1981) 'Australia: economists in a federal system', History of Political Economy 13(3), pp. 405-22.

Reddaway, W.B. (1938) 'Australian wage policy 1929-1937', International Labour Review 38(4), pp. 314-38.

Robertson, D.H. (1940) Essays in Monetary Theory, London: Staples Press.

Royal Commission on the Monetary and Banking System in Australia (1937) Report, Canberra: AGPS.

Schedvin, C.B. (1970) Australia and the Great Depression, Sydney: Sydney University Press.

Sinclair, W.A. (1974) 'External and internal influences in the depression of the 1930s in Australia', Economics 9(4), September, pp. 55-60.

Sutherlin, K. (1980) 'The struggle for central banking in Australia: the Royal Commission of 1935-37 on the Monetary and Banking Systems', Honours Thesis, Department of Economic History, ANU.

Tribe, K. (1997) Economic Careers: Economics and Economists in Britain 19301970, London: Routledge. 